\title{
Parenting Gizi Berbasis Whatsapp: Literasi Digital Guna Mendukung Generasi Sehat Berprestasi
}

\author{
Reni Pawestuti Ambari Sumanto ${ }^{1}$, Henny Puji Astuti², Ni Kadek Aris \\ Rahmadani², R. Agustinus Arum Eka Nugroho $^{2}$ \\ 1, 2 Universitas Negeri Semarang, Indonesia
}

\begin{abstract}
A B S T R A C T
NUTRITIONAL PARENTING ASSISTED WHATSAPP; DIGITAL LITERACY TO SUPPORT THE HEALTHY GENERATION OF ACHIEVERS. Parents have an important role in a family. Parental involvement in childcare has great potential to be developed. The potential of parents in parenting can be optimized through the potential of human and technological resources. In the current digital era, the potential for parental involvement can be strengthened by whatsapp-based digital literacy. Whatsapp is a technology resource that can convey various forms of messages such as text messages, voice messages, picture messages, even voice and video calls. This activity aims to empower parents in providing balanced nutrition for children through whatsapp-based parenting activities. The target group used as partners in this activity are parents of toddlers who attend Pos PAUD, at Pos PAUD Lestari II, Semarang City, Central Java. The method used in this activity was the initiation and parenting of whatsapp continuously. The results of activities carried out in the form of whatsapp-based nutrition parenting groups, the number of participants consisted of 20 parents, the results showed there were $85 \%$ of parents who had high enthusiasm when whatsapp parenting took place and $35 \%$ of parents were able to practice balanced diet for children. This activity needs to be continued given the limited number of parents who can practice balanced diet, the next activity can be in the form of literacy strengthening through peer education activities as an effort to increase parental involvement in fulfilling children's nutritional intake.
\end{abstract}

Keywords: Balance Diet, Digital Literacy, Parenting, Whatsapp.

\begin{tabular}{llll}
\hline Received: & Revised: & Accepted: & Available online: \\
06.01 .2020 & 18.06 .2020 & 21.10 .2020 & 30.11 .2020 \\
\hline
\end{tabular}

Suggested citation:

Ambari Sumanto, R. P., Astuti, H. P., Rahmadani, N. K. A., \& Nugroho, R. A. A. E. (2020). Parenting Gizi Berbasis Whatsapp: Literasi Digital Guna Mendukung Generasi Sehat Berprestasi. Jurnal Pengabdian Pada Masyarakat, 5(4), 1004-1014. https://doi.org/10.30653/002.202054.387

Open Access I URL: http://ppm.ejournal.id/index.php/pengabdian/article/view/387

1 Corresponding Author: Jurusan Pendidikan Guru Pendidikan Anak Usia Dini, FIP Universitas Negeri Semarang; Gedung A3 lantai 1, Kampus UNNES Sekaran, Gunungpati, Kota Semarang, Indonesia. Email: renipawest@mail.unnes.ac.id 


\section{PENDAHULUAN}

Pembangunan sumber daya manusia menjadi fokus pembangunan saat ini. Terwujudnya sumber daya manusia yang berkualitas menjadi salah satu harapan bangsa Indonesia sehingga mampu berdaya saing global. Salah satu tantangan dalam pembangunan sumber daya manusia saat ini adalah optimalisasi masa anak-anak. Masa anak-anak awal menjadi salah satu masa peletakkan pondasi kehidupan dan akan menentukan tahapan kehidupan berikutnya sehingga lazim dikenal dengan masa keemasan.

Pada masa keemasan, orangtua menjadi aktor penting optimalisasi tumbuh kembang anak. Proses tumbuh kembang anak dapat berlangsung optimal dengan dukungan lingkungan dan proses belajar berkelanjutan dalam jangka waktu tertentu. Dukungan lingkungan antara lain tingkat kecukupan gizi terutama energi dan protein yang berhubungan langsung dengan status gizi dan perkembangan anak (Solihin, Anwar, \& Sukandar, 2013). Permasalahan status gizi di Indonesia berdasarkan Riset Kesehatan Dasar (RISKESDAS) pada tahun 2013 antara lain gizi buruk (5.7\%), gizi kurang $(13.9 \%)$, sangat pendek (18\%), pendek (19.2\%), sangat kurus $(5.3 \%)$, kurus $(6.8 \%)$ dan overweigth (11.9\%) (Kementerian Kesehatan RI, 2013). Dibandingkan dengan data RISKESDAS tahun 2007 terdapat peningkatan tren pada status gizi buruk sebesar $0.8 \%$, gizi kurang sebesar $0.9 \%$ dan pendek sebesar 2.1\% (Kementerian Kesehatan RI, 2013). Peningkatan tren status gizi perlu mendapat perhatian dari seluruh elemen masyarakat termasuk keluarga dan keterlibatan Pendidikan Anak Usia Dini (PAUD) sebagai wadah stimulasi tumbuh kembang anak.

Undang-undang Nomor 20 tahun 2003 tentang Sistem Pendidikan Nasional menyatakan keberadaan PAUD bagi anak usia balita atau prasekolah adalah upaya pembinaan yang ditujukan kepada anak sejak lahir sampai dengan umur enam tahun yang dilakukan melalui pemberian rangsangan pendidikan untuk membantu pertumbuhan dan perkembangan jasmani dan rohani agar anak memiliki kesiapan dalam memasuki pendidikan lanjut. Pos PAUD merupakan salah satu bentuk satuan PAUD sejenis yang berada di masyarakat dengan kepemilikan perseorangan atau komunitas tertentu sehingga pelaksanaan kegiatan PAUD belum dapat sepadan dengan PAUD formal yang berada di lingkungan Kementerian Pendidikan. Hal ini perlu mendapat perhatian dari pegiat PAUD untuk dapat memberdayakan Pos PAUD dengan berbagai kegiatan terkait pendidikan yang dapat menstimulasi pertumbuhan anak. Kegiatan parenting merupakan salah satu upaya yang dapat dilakukan secara berkelanjutan untuk mengoptimalkan pertumbuhan anak. Studi di PAUD Permata Hati menunjukkan parenting dapat dilaksanakan oleh orangtua sesuai dengan materi yang telah disampaikan (Monikasari, 2013).

Berbagai bentuk upaya telah dilakukan antara lain upaya peningkatan pengetahuan gizi anak usia dini melalui parenting (Komara dan Putri, 2019), penyampaian konten dalam parenting dapat dilakukan melalui berbagai modal yaitu penggabungan konten berbentuk visual, teks dan audio sekaligus, multimodal saat ini lazim dijumpai melalui media digital (Jones dan Hafner, 2012). Dari bermacam-macam bentuk media digital, whatsapp merupakan salah satu media digital berupa pesan instan yang menduduki peringkat pertama sebagai media yang digunakan masyarakat Indonesia (Trisnani, 2017). 
Studi pendahuluan mengungkap persoalan mitra dalam hal ini orangtua yang berada di Pos PAUD Lestari 2 adalah belum pernah mendapatkan kegiatan parenting dalam bentuk apapun baik dari pihak pemerintah maupun swasta sehingga perlu ada upaya pemberian informasi dan pemberdayaan orangtua terkait asupan gizi pada anak melalui kegiatan parenting. Kegiatan parenting gizi berbasis whatsapp merupakan bentuk literasi digital yang dapat dilakukan secara berkelanjutan, literasi digital dimaknai sebagai kemampuan individu mendapat dan mengolah informasi melalui media digital. Adapun literasi digital dalam parenting gizi memuat bahasan pedoman gizi seimbang yang diharapkan mampu menanggulangi permasalahan gizi anak.

\section{Pedoman Gizi Seimbang}

Dalam upaya mengoptimalkan penyampaian pesan gizi seimbang kepada masyarakat, diperlukan komunikasi, informasi dan edukasi yang tepat dan berbasis masyarakat. Pendidikan dan penyuluhan gizi dengan menggunakan slogan 4 Sehat 5 Sempurna yang dimulai 1952, telah berhasil menanamkan pengertian tentang pentingnya gizi dan kemudian merubah perilaku konsumsi masyarakat. Prinsip 4 Sehat 5 Sempurna yang diperkenalkan oleh Bapak Gizi Indonesia Prof. Poorwo Soedarmo yang terinspirasi dari Basic Four Amerika Serikat yang mulai diperkenalkan pada era 1940an adalah menu makanan yang terdiri dari makanan pokok, lauk pauk, sayuran dan buah-buahan, serta minum susu untuk menyempurnakan menu tersebut. Namun slogan tersebut sudah tidak sesuai lagi dengan perkembangan ilmu dan permasalahan gizi dewasa ini sehingga perlu diperbarui dengan slogan dan visual yang sesuai dengan kondisi saat ini. Prinsip Nutrition Guide for Balanced Diet hasil kesepakatan konferensi pangan sedunia di Roma Tahun 1992 diyakini akan mampu mengatasi beban ganda masalah gizi, baik kekurangan maupun kelebihan gizi.

Di Indonesia prinsip tersebut dikenal dengan Pedoman Gizi Seimbang. Perbedaan mendasar antara slogan 4 Sehat 5 Sempurna dengan Pedoman Gizi Seimbang adalah: Konsumsi makan sehari-hari harus mengandung zat gizi dalam jenis dan jumlah (porsi) yang sesuai dengan kebutuhan setiap orang atau kelompok umur. Konsumsi makanan harus memperhatikan prinsip 4 pilar yaitu anekaragam pangan, perilaku hidup bersih, aktivitas fisik dan memantau berat badan secara teratur untuk mempertahankan berat badan normal (Kemenkes RI, 2014).

\section{Prinsip Gizi Seimbang}

Prinsip Gizi Seimbang terdiri dari 4 (empat) Pilar yang pada dasarnya merupakan rangkaian upaya untuk menyeimbangkan antara zat gizi yang keluar dan zat gizi yang masuk dengan memantau berat badan secara teratur. Empat Pilar tersebut adalah:

1) Mengonsumsi aneka ragam pangan

Tidak ada satupun jenis makanan yang mengandung semua jenis zat gizi yang dibutuhkan tubuh untuk menjamin pertumbuhan dan mempertahankan kesehatannya, kecuali Air Susu Ibu (ASI) untuk bayi baru lahir sampai berusia 6 bulan. Contoh: nasi merupakan sumber utama kalori, tetapi miskin vitamin dan mineral; sayuran dan buahbuahan pada umumnya kaya akan vitamin, mineral dan serat, tetapi miskin kalori dan protein; ikan merupakan sumber utama protein tetapi sedikit kalori. Khusus untuk bayi berusia 0-6 bulan, ASI merupakan makanan tunggal yang sempurna. Hal ini disebabkan 
karena ASI dapat mencukupi kebutuhan untuk tumbuh dan berkembang dengan optimal, serta sesuai dengan kondisi fisiologis pencernaan dan fungsi lainnya dalam tubuh.

Beranekaragam dalam prinsip ini selain keanekaragaman jenis pangan juga termasuk proporsi makanan yang seimbang, dalam jumlah yang cukup, tidak berlebihan dan dilakukan secara teratur. Anjuran pola makan dalam beberapa dekade terakhir telah memperhitungkan proporsi setiap kelompok pangan sesuai dengan kebutuhan yang seharusnya. Contohnya, saat ini dianjurkan mengonsumsi lebih banyak sayuran dan buah-buahan dibandingkan dengan anjuran sebelumnya. Demikian pula jumlah makanan yang mengandung gula, garam dan lemak yang dapat meningkatkan resiko beberapa penyakit tidak menular, dianjurkan untuk dikurangi. Akhir-akhir ini minum air dalam jumlah yang cukup telah dimasukkan dalam komponen gizi seimbang oleh karena pentingnya air dalam proses metabolisme dan dalam pencegahan dehidrasi.

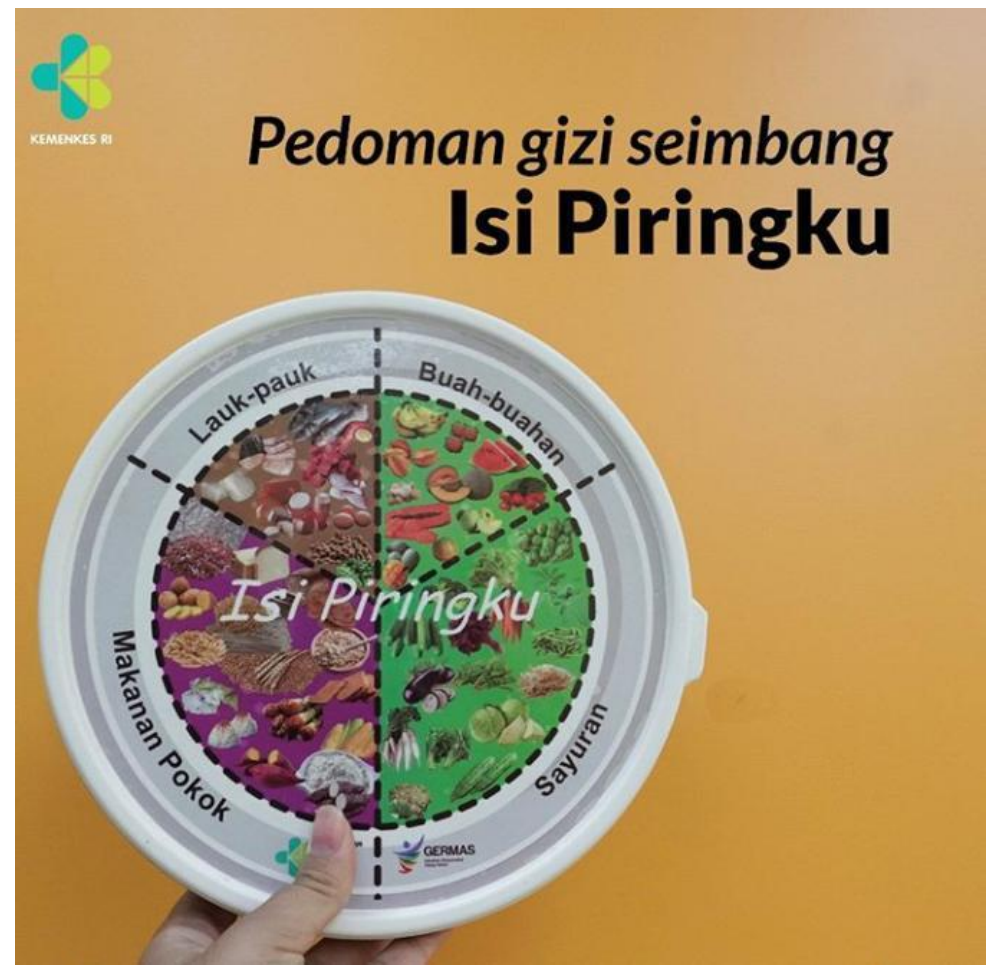

Gambar 1. Isi Piringku

2) Membiasakan perilaku hidup bersih

Penyakit infeksi merupakan salah satu faktor penting yang mempengaruhi status gizi seseorang secara langsung, terutama anak-anak. Seseorang yang menderita penyakit infeksi akan mengalami penurunan nafsu makan sehingga jumlah dan jenis zat gizi yang masuk ke tubuh berkurang. Sebaliknya pada keadaan infeksi, tubuh membutuhkan zat gizi yang lebih banyak untuk memenuhi peningkatan metabolisme pada orang yang menderita infeksi terutama apabila disertai panas. Pada orang yang menderita penyakit diare, berarti mengalami kehilangan zat gizi dan cairan secara langsung akan memperburuk kondisinya. Demikian pula sebaliknya, seseorang yang 
menderita kurang gizi akan mempunyai risiko terkena penyakit infeksi karena pada keadaan kurang gizi daya tahan tubuh seseorang menurun, sehingga kuman penyakit lebih mudah masuk dan berkembang. Kedua hal tersebut menunjukkan bahwa hubungan kurang gizi dan penyakit infeksi adalah hubungan timbal balik. Budaya perilaku hidup bersih akan menghindarkan seseorang dari keterpaparan terhadap sumber infeksi. Contoh: 1) selalu mencuci tangan dengan sabun dan air bersih mengalir sebelum makan, sebelum memberikan ASI, sebelum menyiapkan makanan dan minuman, dan setelah buang air besar dan kecil, akan menghindarkan terkontaminasinya tangan dan makanan dari kuman penyakit antara lain kuman penyakit typus dan disentri; 2) menutup makanan yang disajikan akan menghindarkan makanan dihinggapi lalat dan binatang lainnya serta debu yang membawa berbagai kuman penyakit; 3) selalu menutup mulut dan hidung bila bersin, agar tidak menyebarkan kuman penyakit; dan 4) selalu menggunakan alas kaki agar terhindar dari penyakit kecacingan.

3) Melakukan aktivitas fisik

Aktivitas fisik yang meliputi segala macam kegiatan tubuh termasuk olahraga merupakan salah satu upaya untuk menyeimbangkan antara pengeluaran dan pemasukan zat gizi utamanya sumber energi dalam tubuh. Aktivitas fisik memerlukan energi. Selain itu, aktivitas fisik juga memperlancar sistem metabolisme di dalam tubuh termasuk metabolisme zat gizi. Oleh karenanya, aktivitas fisik berperan dalam menyeimbangkan zat gizi yang keluar dari dan yang masuk ke dalam tubuh.

4) Memantau Berat Badan (BB) secara teratur untuk mempertahankan berat badan normal

Bagi orang dewasa salah satu indikator yang menunjukkan bahwa telah terjadi keseimbangan zat gizi di dalam tubuh adalah tercapainya berat badan yang normal, yaitu berat badan yang sesuai untuk tinggi badannya. Indikator tersebut dikenal dengan Indeks Masa Tubuh (IMT). Oleh karena itu, pemantauan BB normal merupakan hal yang harus menjadi bagian dari 'Pola Hidup' dengan 'Gizi Seimbang', sehingga dapat mencegah penyimpangan BB dari BB normal, dan apabila terjadi penyimpangan dapat segera dilakukan langkah-langkah pencegahan dan penanganannya. Bagi bayi dan balita indikator yang digunakan adalah perkembangan berat badan sesuai dengan pertambahan umur. Pemantauannya dilakukan dengan menggunakan KMS (Kemenkes RI, 2014).

\section{Perilaku orangtua}

Perilaku orangtua dimaknai sebagai praktik seseorang yang telah mengetahui stimulus/objek kesehatan, kemudian mengadakan penilaian atau pendapat terhadap apa yang diketahui, proses selanjutnya diharapkan ia akan melaksanakan/mempraktikkan apa yang diketahui atau disikapi (dinilai baik) (Notoatmodjo, 2012).

Suatu sikap belum otomatis terwujud dalam suatu tindakan (overt behaviour) untuk terwujudnya sikap menjadi suatu perbedaan nyata diperlukan faktor pendukung atau suatu kondisi yang memungkinkan, antara lain adalah fasilitas. Selain faktor fasilitas juga diperlukan juga diperlukan faktor dukungan (support) dari pihak lain. 
1) Persepsi

Mengenal dan memilih berbagai objek sehubungan dengan tindakan yang akan diambil merupakan praktik tingkat pertama.

2) Respon terpimpin (Guided respons)

Dapat melakukan sesuatu sesuai dengan urutan yang benar sesuai dengan contoh adalah indikator praktik tingkat dua.

3) Mekanisme (Mecanism)

Apabila seseorang telah melakukan sesuatu dengan benar secara otomasis atau sesuatu itu sudah merupakan kebiasaan maka ia sudah mencapai praktik tingkat tiga.

4) Adaptasi (Adaptation):

Adaptasi adalah suatu praktik atau tindakan yang sudah berkembang dengan baik artinya tindakan itu sudah dimodifikasinya sendiri tanpa mengurangi kebenaran tindakannya tersebut.

Praktik kesehatan atau tindakan untuk hidup sehat adalah semua kegiatan atau aktivitas orang dalam rangka memelihara kesehatan. Mengukur perilaku terbuka, praktik atau tidakan relatif lebih mudah bila dibandingkan dengan mengukur perilaku tertutup (pengetahuan dan sikap).

Green mengidentifikasi tiga faktor yang mempengaruhi perilaku individu atau kelompok, mencakup organizational actions dalam hubungannya dengan lingkungan, dimana masing-masing mempunyai tipe yang berbeda dalam mempengaruhi perilaku, yaitu faktor predisposisi (predisposising factor), faktor pemungkin (enabling factor) dan faktor penguat (reinforcing factor). Menurut Green, perilaku dipengaruhi oleh tiga faktor utama, yaitu (Notoatmodjo, 2012):

1) Faktor predisposisi (Predisposising factor)

Faktor predisposisi adalah faktor-faktor yang mendahului perilaku, dimana faktor tersebut memberikan alasan atau motivasi untuk terjadinya suatu perilaku. Faktorfaktor ini mencakup pengetahuan, sikap, tradisi dan kepercayaan, sistem nilai yang dianut, kepercayaaan dan kemampuan yang berhubungan dengan motivasi individu atau kelompok untuk berperilaku.

Faktor predisposisi mencakup dimensi kognitif dan afektif dari knowing, feeling dan believing, valuing dan half self confidence atau self efficacy. Faktor-faktor yang berkaitan dengan variasi demografi, seperti status sosial ekonomi, umur dan jenis kelamin, dan jumlah keluarga juga termasuk predisposisi. Faktor-faktor tersebut tidak dimasukkan dalam daftar predisposising factors hanya karena mereka tidak dapat secara mudah dan secara langsung dapat dipengaruhi dengan program promosi kesehatan.

Secara umum kita dapat mengatakan bahwa faktor predisposisi adalah sebagai "the personal preferences hat an individual or group brings to a behavioural on environmental choice, or to an educational or organizational experience". Preferen-preferen ini bisa mendorong atau menghambat perilaku.

2) Faktor pemungkin (Enabling factor)

Didalam model PRECEDE-PROCEED, faktor pemungkin digambarkan sebagai faktor-faktor yang memungkinkan (membuat lebih mudah) individu atau populasi untuk merubah perilaku atau lingkungan mereka. Faktor pemungkin meliputi 
ketersediaan, keterjangkauan dan kemampuan fasilitas pelayanan kesehatan serta sumberdaya yang tersedia di masyarakat, kondisi kehidupan, dukungan sosial dan ketrampilan-ketrampilan yang memudahkan untuk terjadinya suatu perilaku. Juga termasuk kondisi lingkungan yang bertindak sebagai penghalang untuk melakukan sesuatu perilaku, seperti ketersediaan alat transportasi, sumber-sumber (resources) dan ketrampilan baru yang diperlukan individu, kelompok atau masyarakat untuk berperilaku atau merubah lingkungan.

3) Faktor penguat (Reinforcing factor)

Faktor penguat adalah konsekuensi dari perilaku yang ditentukan apakah pelaku menerima umpan balik positif atau negatif dan mendapat dukungan sosial setelah perilaku dilakukan. Faktor penguat mencakup dukungan sosial, pengaruh sebaya serta advise dan umpan balik dari tenaga kesehatan. Faktor penguat juga mencakup akibat secara fisik dari perilaku yang dilakukan. Keuntungan sosial (seperti penghargaan), keuntungan fisik (seperti kenyamanan, kebugaran, bebas dari nyeri), tangible rewards (seperti keuntungan ekonomi, tidak mengeluarkan biaya) dan imagine atau vicarious rewards (seperti peningkatan penampilan dan harga diri), semuanya akan memperkuat perilaku. Faktor penguat juga akibat kurang baik atau "punishment" yang dapat mendorong ke arah penghentian perilaku positif. Reinforcement negative merupakan reward alternatif untuk perilaku yang salah.

\section{METODE}

Pemberdayaan masyarakat dalam kegiatan ini melibatkan 20 orangtua yang memiliki anak balita di Pos PAUD Lestari 2, Kecamatan Gunungpati, Kota Semarang melalui metode kegiatan : 1). Inisiasi kegiatan parenting dengan para orangtua meliputi kegiatan perkenalan, berbagi pengalaman terkait pemenuhan asupan gizi sehari-hari kepada anak dan pembentukan grup whatsapp sebagai wadah komunikasi dalam kegiatan parenting. 2). Parenting gizi berbasis whatsapp dilakukan secara berkelanjutan, pemberian materi sesuai pesan gizi seimbang dilakukan sebanyak 2 kali seminggu dan diskusi berlangsung tanpa batasan waktu. Kegiatan ini dilakukan dengan koordinasi dengan pelaksana Pos PAUD Lestari 2 sehingga elaborasi antara kegiatan Parenting Gizi berbasis Whatsapp dan kegiatan Pos PAUD terwujud sebagai salah satu bentuk integrasi Pos PAUD.

\section{HASIL DAN PEMBAHASAN}

Hasil kegiatan inisiasi parenting gizi berbasis whatsapp menunjukkan bahwa sebanyak 20 orangtua dari 24 orangtua ( $83 \%$ ) hadir, seluruh peserta yang hadir bersedia mengikuti kegiatan parenting gizi dan menjadi anggota dalam grup whatsapp parenting gizi. Sharing pengalaman terkait pemenuhan asupan gizi pada tahap inisiasi memberikan gambaran bahwa seluruh orangtua memiliki kendala dalam pemberian asupan gizi pada anak antara lain anak susah makan, makanan yang tidak beranekaragam dan masih berpedoman pada 4 sehat lima sempurna yaitu susu sebagai minuman penyempurna makanan. 


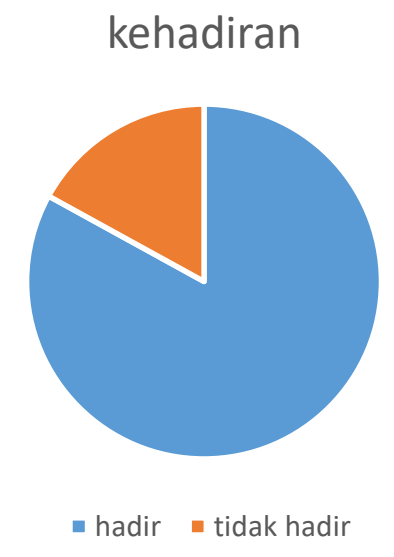

Gambar 2. Kehadiran orangtua dalam inisiasi parenting gizi

Setelah melakukan inisiasi, kegiatan parenting dilanjutkan dengan kegiatan parenting gizi melalui grup whatsapp. Kegiatan ini dimaksudkan agar orangtua mendapatkan informasi secara berkelanjutan mengenai pesan gizi seimbang. Transfer informasi dilakukan melalui pesan gambar, pesan teks juga video. Sebanyak $85 \%$ orangtua dalam grup whatsapp menunjukkan antusias yang tinggi dalam proses diskusi grup whatsapp berlangsung. Setelah dilakukan pemberian materi sebanyak 12 kali, evaluasi parenting gizi berupa praktik membuat olahan makanan sesuai "isi piringku" oleh masing-masing orangtua. Evaluasi menunjukkan sebanyak 35\% orangtua mampu mempraktikkan porsi makan gizi seimbang untuk anak dalam satu kali makan.

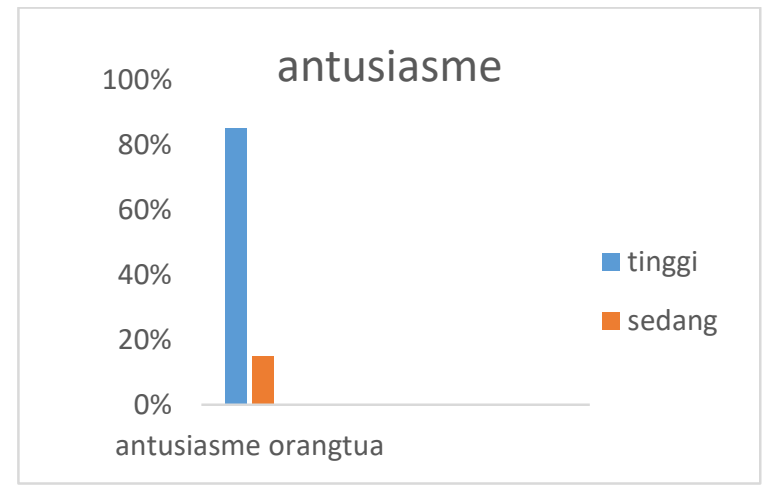

Gambar 3. Antusiasme orangtua dalam parenting gizi berbasis whatsapp

Sebanyak $85 \%$ orangtua memiliki respon positif ditandai dengan antusiasme yang tinggi pada saat kegiatan parenting gizi berbasis whatsapp. Respon positif orangtua menjadi salah satu indikator keberhasilan penyampaian materi sehingga dapat membentuk pengetahuan orangtua tentang gizi seimbang. Pengetahuan merupakan faktor penting yang mempengaruhi perilaku gizi individu, keluarga dan masyarakat (Demirozu, Pehlivan, \& Camliguney, 2012). 


\section{praktik "isi piringku"}

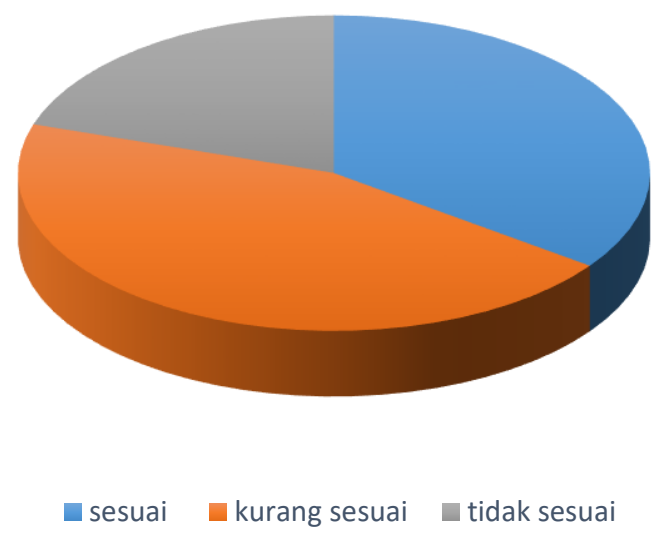

Gambar 4. Praktik "Isi Piringku"

Praktik "isi priringku" menunjukkan sebanyak 35\% orangtua telah sesuai, $45 \%$ kurang sesuai dan $20 \%$ tidak sesuai melakukan praktik penyajian menu gizi seimbang. Praktik adalah respon seseorang terhadap suatu rangsangan. Setelah seseorang mengetahui stimulus atau objek, kemudian mengadakan penilaian atau pendapat terhadap apa yang diketahui, proses selanjutnya diharapkan ia akan melaksanakan apa yang diketahui atau disikapinya (Notoatmodjo, 2012). Praktik yang didasari oleh pengetahuan akan bertahan sehingga sumber pengetahuan menjadi penting, sumber pengetahuan melalui media android dan website efektif meningkatkan pengetahuan gizi (Perdana, Madanijah, \& Ekayanti, 2017). Parenting gizi berbasis whatsapp merupakan kegiatan pemberdayaan masyarakat terutama orangtua untuk mengurangi gangguan gizi yang dapat terjadi pada anak. Pemberdayaaan serta peran serta masyarakat sejak awal dengan promosi kesehatan dan mengembangkan serta mengoptimalkan potensi masyarakart yang ada merupakan hal yang baik dalam pelaksanaannya (Dewi et al, 2013). Pemberdayaan masyarakat bertujuan untuk mewujudkan kemampuan masyarakat dalam meningkatkan kesehatan mereka (Sagrim, Noor, Thaha, \& Maidin, 2015). Sehingga semua sektor harus terlibat baik pemerintah maupun masyarakat dalam membangun lingkungan yang kondusif untuk hidup sehat (Dans et al, 2011).

\section{SIMPULAN}

Inisiasi kegiatan parenting gizi berbasis whatsapp dihadiri oleh $83 \%$ orangtua dari total orangtua yang terdaftar dalam Pos PAUD Lestari 2 dan seluruh orangtua yang hadir memiliki kendala dalam pemenuhan asupan gizi pada anak. Tahap akhir inisiasi adalah pembentukan grup whatsapp parenting gizi yang diikuti oleh seluruh orangtua yang hadir.

Antusias tinggi ditunjukkan oleh $85 \%$ orangtua pada saat parenting gizi berbasis whatsapp berlangsung dan evaluasi kegiatan melalui praktik isi piringku adalah $35 \%$. 


\section{Ucapan Terima Kasih}

Penulis mengucapkan terimakasih kepada pengelola dan orangtua Pos PAUD Lestari yang telah berpartipasi dalam kegiatan parenting gizi berbasis whatsapp dan khususnya kepada Fakultas Ilmu Pendidikan Universitas Negeri Semarang yang telah memfasilitasi pengabdian kepada masyarakat ini.

\section{REFERENSI}

Dans, A., Ng, N., Varghese, C., Tai, E. S., Firestone, R., \& Bonita, R. (2011). The rise of chronic non-communicable diseases in Southeast Asia: Time for action. The Lancet, 377(9766), 680-689. https://doi.org/10.1016/S01406736(10)61506-1

Demirozu, B. E., Pehlivan, A., \& Camliguney, A. F. (2012). Nutrition knowledge and behaviours of children aged 8-12 who attend sport schools. Procedia-Social and Behavioral Sciences, 46, 4713-4717.

Dewi, F. S. T., Stenlund, H., Marlinawati, V. U., Öhman, A., \& Weinehall, L. (2013). A community intervention for behaviour modification: an experience to control cardiovascular diseases in Yogyakarta, Indonesia. BMC public health, 13(1), 1043.

Jones, R. H., \& Hafner, C. A. (2012). Understanding digital literacies: A practical introduction. Oxford: Routledge.

Kementerian Kesehatan Republik Indonesia. (2013). Hasil Utama Riset Kesehatan Dasar. Jakarta: Badan Penelitian dan Pengembangan Kesehatan Kementerian RI.

Kementerian Kesehatan Republik Indonesia. (2014). Peraturan Menteri Kesehatan Republik Indonesia Nomor 41 Tahun 2014 Tentang Pedoman Gizi Seimbang. Jakarta: Kementerian Kesehatan RI

Komara, I., \& Putri, N. N. (2019). Upaya meningkatkan pengetahuan gizi anak usia dini melalui parenting. Journal on Education, 1(4), 612-615.

Monikasari, C. (2013). Pelaksanaan program parenting bagi orang tua peserta didik di PAUD Permata Hati. Diklus: Jurnal Pendidikan Luar Sekolah, 17(1), 281-291.

Notoatmodjo. (2012). Pendidikan dan perilaku kesehatan. Jakarta: Rineka Cipta.

Perdana, F., Madanijah, S., \& Ekayanti, I. (2017). Pengembangan media edukasi gizi berbasis android dan website serta pengaruhnya terhadap perilaku tentang gizi seimbang siswa sekolah dasar. Jurnal Gizi dan Pangan, 12(3), 169-178.

Sagrim, M., Noor, N. N., Thaha, R. M., \& Maidin, A. (2015). Kearifan lokal komunitas adat terpencil suku taburta dalam perilaku hidup bersih dan sehat berbasis rumah tangga. Media Kesehatan Masyarakat Indonesia, 11(4), 218-227.

Solihin, R. D. M., Anwar, F., \& Sukandar, D. (2013). Kaitan antara status gizi, perkembangan kognitif, dan perkembangan motorik pada anak usia prasekolah. Nutrition and Food Research, 36(1), 62-72. 
Trisnani. (2017). Pemanfaatan whatsapp sebagai media komunikasi dan kepuasaan dalam penyampaian pesan di kalangan tokoh masyarakat. Jurnal Komunikasi, Media dan Informatika, 6(3), 1-12.

Undang-Undang Nomor 20 Tahun 2003 Tentang Sistem Pendidikan Nasional.

\section{Copyright and License}

This is an open access article distributed under the terms of the Creative Commons Attribution 4.0 International License, which permits unrestricted use, distribution, and reproduction in any medium, provided the original work is properly cited.

(C) 2020 Reni Pawestuti Ambari Sumanto, Henny Puji Astuti, Ni Kadek Aris Rahmadani,

R. Agustinus Arum Eka Nugroho.

Published by LP3M of Universitas Mathla'ul Anwar Banten in collaboration with the Asosiasi Jurnal Pengabdian Kepada Masyarakat (AJPKM) 